\title{
THE WATER ECONOMY OF HARVEST MICE FROM XERIC AND MESIC ENVIRONMENTS ${ }^{1}$
}

\author{
MARJORIE L. REAKA2 AND KENNETH B. ARMITAGE \\ Division of Biological Sciences, University of Kansas, Lawrence, Kansas 66045
}

(Accepted 4/22/76)

\begin{abstract}
Populations of Reithrodontomys megalotis from mesic and xeric environments in eastern and western Kansas, respectively, were maintained in the laboratory on ad lib and restricted water regimens at 20 and $33 \mathrm{C}$ and at $12 \%$ and $95 \%$ relative humidity (RH). The western animals survived a mean of $179.3 \mathrm{~h}$ and the eastern animals $82.9 \mathrm{~h}$ in a tolerance experiment at $35 \mathrm{C}<15 \% \mathrm{RH}, 0.25 \mathrm{ml}$ water. The western animals tolerated more weight loss before death. Body temperature, water consumption, food consumption, urine volume, fecal water content, fecal water loss, and urine concentrations of $\mathrm{K}^{+}, \mathrm{Na}^{+}$, urea, and hematocrit were significantly affected by the temperature-humidity and water regimens. Evaporative water loss was significantly affected by temperature and differed significantly between populations. The population from the xeric environment was adapted to a small water flux, low metabolism and body temperature, low evaporative cooling per gram body weight, and tolerance of desiccation. The population from the mesic environment was adapted to a large water flux, high metabolism and body temperature, tolerance of a heat load when water was abundant, and high evaporative cooling relative to metabolic rate.
\end{abstract}

\section{INTRODUCTION}

Terrestrial organisms must maintain a largely aqueous internal environment while living in a dry external environment. Because of the difficulty of maintaining this homeostasis, water is a limiting factor in many terrestrial populations. Mechanisms for obtaining and conserving water from extremely dry environments have evolved in only a few animals; insects, arachnids, and desert rodents have been some of the most successful.

The diverse mechanisms by which

\footnotetext{
1 This work was supported by an NSF summer fellowship for teaching assistants and a graduate state fellowship to M. Reaka, a grant from the Kansas Academy of Science, grant 1262 from the University of Kansas computation center, and NSF grant GB4446X for systematics and evolutionary biology awarded to the University of Kansas. Dr. M. J. Maher offered helpful suggestions on the manuscript, and D. R. Michener, J. Standing, and E. I. Lindquist provided valuable assistance in the field and laboratory.
}

${ }^{2}$ Present address: Department of Zoology, University of Maryland, College Park, Maryland 20742. desert rodents adapt to heat and lack of water have been the subject of several investigations. However, most studies have tested water balance with only one environmental variable; the water balance of a species depends not only on free water available in the environment, but on humidity and temperature. Because these variables act on rodents in their natural environment, this study tests the effects of water regimen, temperature, and humidity on the water balance of a small semidesert rodent, Reithrodontomys megalotis (Baird).

Most studies tested only one aspect of the various adaptations of obtaining or conserving water. One parameter, for example, evaporative water loss or urine concentrations, cannot indicate how the animal as a whole maintains water balance or to what degree the animal is adapted to a particular environment. Therefore, this study attempts to test the relative importance of free water obtained, unbound water obtained in 
food, metabolic water produced, and water lost in urine, in feces, and in evaporation.

Reithrodontomys megalotis is widely distributed in a variety of habitats, mostly in arid grasslands. Some populations occur in salt marshes in California. Although studies of inland and salt marsh populations of $R$. megalotis (Fisler 1963; MacMillen 1964) and of $R$. raviventris (Haines 1964) pertain mostly to salt and water balance, these studies provide data for comparing physiological evolution in Reithrodontomys from various environments. In order to determine whether physiological divergence has occurred in populations of the same species from different habitats, this study examines water balance in two populations, one from xeric grasslands in western Kansas and one from mesic grassland plots in eastern Kansas.

\section{CLIMATE AND ECOLOGICAL OBSERVATIONS}

Climatological data compiled for Sublette (Haskell County) and Lawrence (Douglas County) (U.S. Department of Commerce, Weather Bureau 1957-1967, $1962,1964)$ show that the western population is subjected to at least 1-5 C lower temperatures and 3\%-13\% lower relative humidities at night and 2-5 C higher temperatures and $20 \%$ lower relative humidities by day than the eastern population. Reithrodontomys megalotis in California at approximately the same latitude as Kansas is most active within an hour after sunset in winter but in the $5 \mathrm{~h}$ before sunrise in June, July, and August (Pearson 1960a). If we assume a similar activity period in Kansas, the animals would encounter a mean monthly maximum temperature of about $20 \mathrm{C}$ in eastern Kansas and 18.5 C in western Kansas. Mean yearly total precipitation is 17.3 inches at Sublette and 34.5 inches at Lawrence. In addition to receiving less frequent and smaller rainfalls, the sandy western Kansas soil is more porous than that of eastern Kansas and does not retain as much surface water. Dew was never observed, even at dawn, while we were collecting from June to August 1966 at the Haskell County collecting sites; dew was commonly observed in Douglas County. There are no streams or pools of water at any of the collecting sites. The mean wind speed 1.8 $\mathrm{m}$ above the surface for Dodge City ( $80 \mathrm{~km} \mathrm{NE}$ of Sublette) is $23.5 \mathrm{~km} / \mathrm{h}$ and for Topeka (34 km W of Lawrence) 18.4 $\mathrm{km} / \mathrm{h}$. The vegetation at collecting sites in western Kansas is more sparse and clumped than in eastern Kansas, reducing the humidity and moisture retention of the soil. An estimated $60 \%$ of the soil was bare in the abandoned field where collections were made in Haskell County; in contrast, the soil was almost completely covered with vegetation in Douglas County.

Therefore, different macroenvironments exist where the two populations occur and the microclimates probably also differ for the following reasons: (1) The burrows and nests of most rodents represent a moderated microenvironment. However, $R$. megalotis does not modify its microenvironment as much as other desert species, because this harvest mouse does not dig burrows but nests near the surface of the ground or under rocks and above ground in grasses and shrubs (Hall 1955; Fisler 1965). In contrast to eastern Kansas, few if any runways are used in western Kansas because of the paucity of vegetation. (2) The low temperature and humidity of the macroenvironment in western Kansas relative to eastern Kansas apply to the microenvironment because of the wind, the porous nature of the soil, and the sparse vegetation. The high tem- 
peratures and high humidities found in eastern Kansas are further increased at the level of the microhabitat because of the low wind, the nonabsorbance of water into the soil, and the insulation and transpiration of the dense vegetation.

The above arguments for the effects of climate and vegetation on harvest mice suggest that the factors of temperature, humidity, and available water may have a differential effect on populations of mice from Douglas and Haskell counties. One might expect variation in the physiology of heat and water regulation between the two populations.

\section{MATERIAL AND METHODS}

Western harvest mice were trapped live in Douglas and Johnson counties within 20 miles of Lawrence, Kansas, and in Haskell County between Sublette and Satanta, Kansas. All animals maintained weight in the laboratory under conditions of $21-23 \mathrm{C}, 15 \%-25 \%$ relative humidity, normal day length, and ad libitum food (scratch grain and Purina Laboratory Chow) and water. All animals were maintained in the laboratory at least 1 mo before experimental use. Only nonbreeding adults were used.

Animals were kept in growth chambers maintained at $33.0 \pm 0.5 \mathrm{C}$ or $20.0 \pm 0.5$ $\mathrm{C}$ at a photoperiod of $12 \mathrm{~L}: 12 \mathrm{D}$. Trays of saturated salt solutions maintained relative humidities at either $95 \% \pm 5 \%$ $\left(\mathrm{K}_{2} \mathrm{Cr}_{2} \mathrm{O}_{7}\right)$ or $12 \% \pm 5 \%\left(\mathrm{LiCl}_{2}\right)$ (Winston and Bates 1960). The combination of temperature and relative humidity produced a range of vapor pressure deficits (col. "VPD," table 2).

Four sequential experiments of 21 days each were conducted at $33 \mathrm{C}, 95 \%$ $\mathrm{RH}$ (relative humidity); $20 \mathrm{C}, 95 \% \mathrm{RH}$; $33 \mathrm{C}, 12 \% \mathrm{RH}$; and $20 \mathrm{C}, 12 \% \mathrm{RH}$. Different animals were used in each experiment. Fourteen individuals from each of the two populations were distributed in individual containers placed alternately in the experimental chamber. Each group of 14 was subdivided into seven animals on ad lib and seven on restricted water regimen and were also distributed alternately in the chamber. These four groups will be referred to as Eal (eastern population, ad lib water), Er (eastern population, restricted water), Wal (western population, ad lib water), and $W r$ (western population, restricted water).

Water for animals on ad lib consumption was provided in $15-\mathrm{ml}$ centrifuge tubes calibrated to $0.1 \mathrm{ml}$. Individuals on restricted water regimens drank the 0.5-ml daily ration immediately (for details of housing, feeding, etc., see Reaka [1969]).

Equal amounts of scratch grain were given to each animal. The amount of food eaten was determined by weighing it before placing it in the container and weighing the portions remaining, less feces, after 4 days (days 14-18 of each experiment). The amount of preformed water obtained from the food was determined by drying control samples of grain at $60 \mathrm{C}$ for $3 \mathrm{wk}$.

Urine was collected under mineral oil in 15-ml calibrated centrifuge tubes from 2000 to $0200 \mathrm{~h}$ on days $1,7,14$, and 21 of the experiment. No food was available during these $6 \mathrm{~h}$.

Water content of feces was determined by collecting feces from each animal as it defecated while being handled, placing the feces in a preweighed polypropylene cup, weighing the cup and feces to 0.01 $\mathrm{mg}$, and drying the feces for $1 \mathrm{wk}$ at 60 C. Fecal production as number of feces per day was determined during days 14-18.

Body weight was measured to $0.1 \mathrm{~g}$ on days $1,6,11,16$, and 21 . On day 21 of each experiment, body temperature 
was measured by placing a telethermometer probe $1 \mathrm{~cm}$ into the rectum. Each animal was removed from the experimental chamber and tested immediately. Also, a blood sample was taken with a heparinized hematocrit tube from the dorsolateral caudal vein of each animal. Hematocrits were determined and the plasma portion sealed and frozen. All samples from animals at $33 \mathrm{C}$ and $95 \% \mathrm{RH}$ were lost.

Sodium and potassium ion concentrations were determined for plasma and urine samples with calibrated Thomas $\mathrm{Na}^{+}$and $\mathrm{K}^{+}$ion electrodes. Urea content of the urine samples was measured according to the Harnstoff-Farb Colorimetric Test for urea.

For most factors, replicate measurements were made for each individual. The mean of these replicates provided a more reliable estimate of the value for an individual animal and thus increased the reliability of the data. The calculated mean is the population mean; therefore, $N$ represents the number of individual means in the analysis.

Results of the four sequential experiments were tested by multiway analysis of variance of a factorial design (Sokal and Rohlf 1969, p. 343), except for water consumption, which was tested by two-way analysis of variance in a randomized block design (Sokal and Rohlf 1969, p. 324).

The evaporative water loss of 20 animals from each population maintained under normal laboratory conditions for at least 6 mo was measured at 25 and at $35 \mathrm{C}$. Air was passed through two $20-\mathrm{cm}$ drying tubes filled with $\mathrm{CaSO}_{4}$ into a sealed pint glass animal container in a covered water bath and then into two consecutive $10-\mathrm{cm}$ tubes filled with $\mathrm{CaSO}_{4}$. The flow rate was $700-720 \mathrm{ml} / \mathrm{min}$, measured before the air entered the animal container and when it emerged from the last drying tube. This high flow rate prevented variations in vapor pressure and evaporation (Lasiewski, Acosta, and Bernstein 1966). Mineral oil in the bottom of the animal container ensured only evaporative water loss. Tests were run between 0900 and 1800. Results were tested by a two-way analysis of variance with replication (Sokal and Rohlf 1969, p. 301).

Twelve animals from each locality were subjected to a tolerance-of-xericconditions test of 14 days at $35 \mathrm{C}$, $<15 \% \mathrm{RH}, 12-\mathrm{h}$ photoperiod, and a daily water regimen of $0.25 \mathrm{ml}$. Scratch grain was provided ad lib. Body weights were recorded every 2 days and at death. These animals had been under normal laboratory conditions for at least 6 mo. Results were tested by singleclassification analysis of variance.

Oxygen consumption was calculated from the oxygen required to metabolize food. Values for food composition were taken from Kent-Jones and Amos (1957), and the amount of oxygen required for each organic component of the food was taken from Schmidt-Nielsen (1964, p. $30)$. From these values the amount of oxygen needed to metabolize $1 \mathrm{~g}$ of food was calculated. The amount of food consumed per day multiplied by the amount of oxygen needed to metabolize $1 \mathrm{~g}$ of food equaled the amount of oxygen consumed per day, which was converted to milliliters of $\mathrm{O}_{2}$ per gram body weight per hour.

Metabolic water was calculated similarly from food composition and the grams of metabolic water formed from $1 \mathrm{~g}$ of nutrient (Schmidt-Nielsen 1964).

\section{RESULTS}

A. TOLERANCE OF XERIC CONDITIONS

Animals alive after 14 days were considered to have survived $336 \mathrm{~h}$. Western animals survived a mean of 


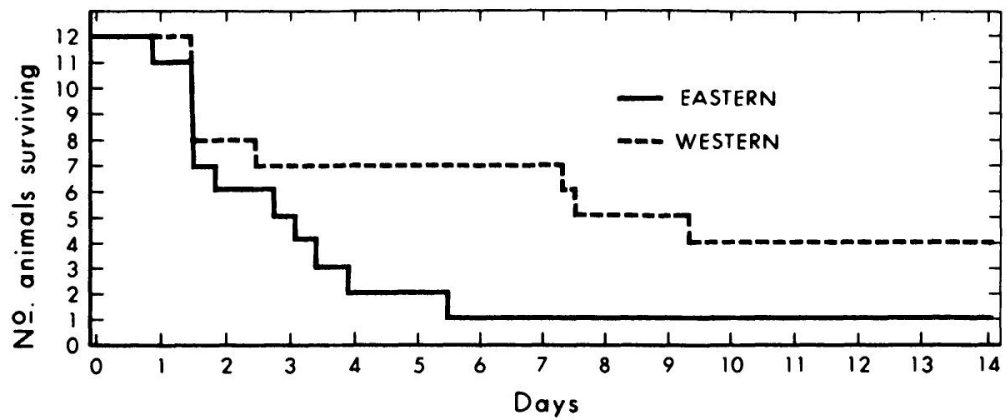

F1G. 1.-Survival curve for each population of Reithrodontomys megalotis at $35 \mathrm{C},<15 \% \mathrm{RH}, 0.25 \mathrm{ml}$ water/day.

$179.3 \mathrm{~h}$ (about 7.5 days); eastern animals survived a mean of $82.9 \mathrm{~h}$ (about 3.5 days) (fig. 1). The western mice survived significantly longer $(P<.01)$ under the experimental xeric conditions.

The western Kansas animals tolerated more weight loss before death than did the eastern populations. At death the western group weighed a mean of 7.53 $\mathrm{g}, 61.5 \%$ of their original weight; the eastern group weighed a mean of $8.15 \mathrm{~g}$, $73.1 \%$ of their original weights. The single survivor of the eastern population maintained a weight comparable to the weights of the four western survivors.

A high-temperature-tolerance experiment was performed accidentally when the temperature of an experimental chamber rose to $43 \mathrm{C}$, unknown humidity, for more than $1 \mathrm{~h}$. Four of seven Eal animals survived; only one of seven Wal animals survived. All animals from both populations on restricted water died. Although the numbers are small, the results suggest that the availability of water considerably improves the tolerance of eastern animals to high temperatures, whereas most western animals are unable to withstand extremely high temperatures. B. WEIGHT RESPONSES IN SEQUENTIAL
EXPERIMENTS

Initial weights averaged $11.7 \pm 0.98 \mathrm{~g}$ for the eastern population and $13.3 \pm$
$1.07 \mathrm{~g}$ for the western population. Weight changes at $20 \mathrm{C}$ were not statistically significant for any of the eastern populations $(t=0.34-1.1$, all $P>.2$ ) or western populations $(t=0.66-1.6, P>.1)$, except possibly the $W a l$ animals $(t=$ $1.84, .1>P>.05$ ).

All animals lost weight at $33 \mathrm{C}$ and 95\% RH $(t=2.4-4.5$, all $P<.05)$; there were no significant differences among groups. At $33 \mathrm{C}$ and $12 \% \mathrm{RH}$, the $\operatorname{Eal}(t=3.1, P=.01)$ and $\operatorname{Wal}(t=$ $2.5, P=.02)$ animals gained weight and the $\operatorname{Er}(t=5.5, P<.001)$ animals lost weight. After an initial weight loss, the $W r$ animals returned to their original weights (fig. 2). The weight change of the Er animals was significantly different from all other groups; the weight change of the Eal and Wal animals was significantly different from that of the $W r$ animals but not from that of each other (all $P \leq .05$ ).

\section{BEHAVIOR}

In the evaporation experiment at 35 and at $33 \mathrm{C}$ the animals lay flattened with all four limbs extended. All animals were quiescent except one individual, which became hyperactive and died. At 20 and $25 \mathrm{C}$, the animals usually sat quietly upright and often groomed themselves.

Unquantified observations of behavior of the two populations indicated that 
the eastern mice are more "high strung" than the western mice. The eastern animals were consistently more active, usually had to be maintained in individual cages, sometimes ate their young, bit more when handled, were harder to catch when they escaped, and generally evidenced more stress under maintenance and test conditions than the western group. In contrast, western animals were maintained easily in groups of up to four, reared litters in the laboratory, and were much easier to handle.

\section{BODY TEMPERATURE}

Body temperature was significantly affected by the temperature-humidity regimen (table 1). Mean body temperatures were lower at the lower humidities at each of the experimental temperatures (fig. 3). Overall, mice of the western population had lower mean body tem- peratures than mice from the eastern population. This difference was greatest at $20 \mathrm{C}$ and $12 \% \mathrm{RH}$ (fig. 3). The lowest body temperatures were $35 \mathrm{C}$, recorded at $33 \mathrm{C}$ and $12 \% \mathrm{RH}$, which coincides with the highest vapor pressure deficit (VPD) (table 2).

\section{E. WATER CONSUMPTION}

Water consumption varied among the four temperature-humidity regimens (table 2); this variation may be biologically significant $(F[3,3]=5.8, P=$ .1 ) because of high consumption at $33 \mathrm{C}$ and $12 \% \mathrm{RH}$. Members of the western population drank significantly less water $(F[1,3]=16.7, P=.05)$ than members of the eastern population. Less drinking by the western mice occurred at all temperature-humidity regimens (table 2). The higher standard errors of the means of the eastern population in comparison
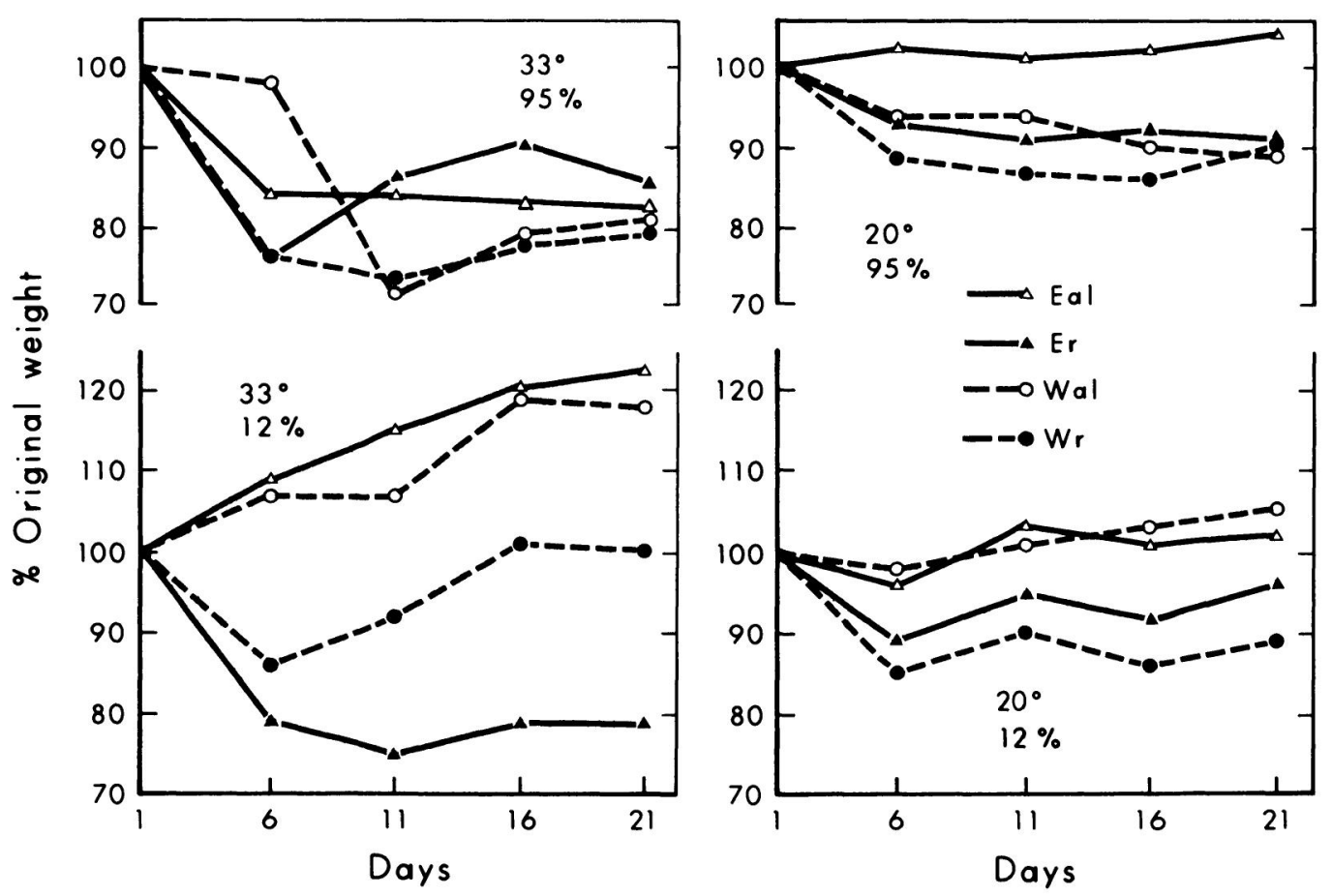

FIG. 2.-Weight responses of harvest mice to four experimental conditions. $N=7$ in each group. 
TABLE 1

ANOVA FOR SEQUENTIAL EXPERIMENTS, FACTORIAL DESIGN ${ }^{\mathrm{a}}$

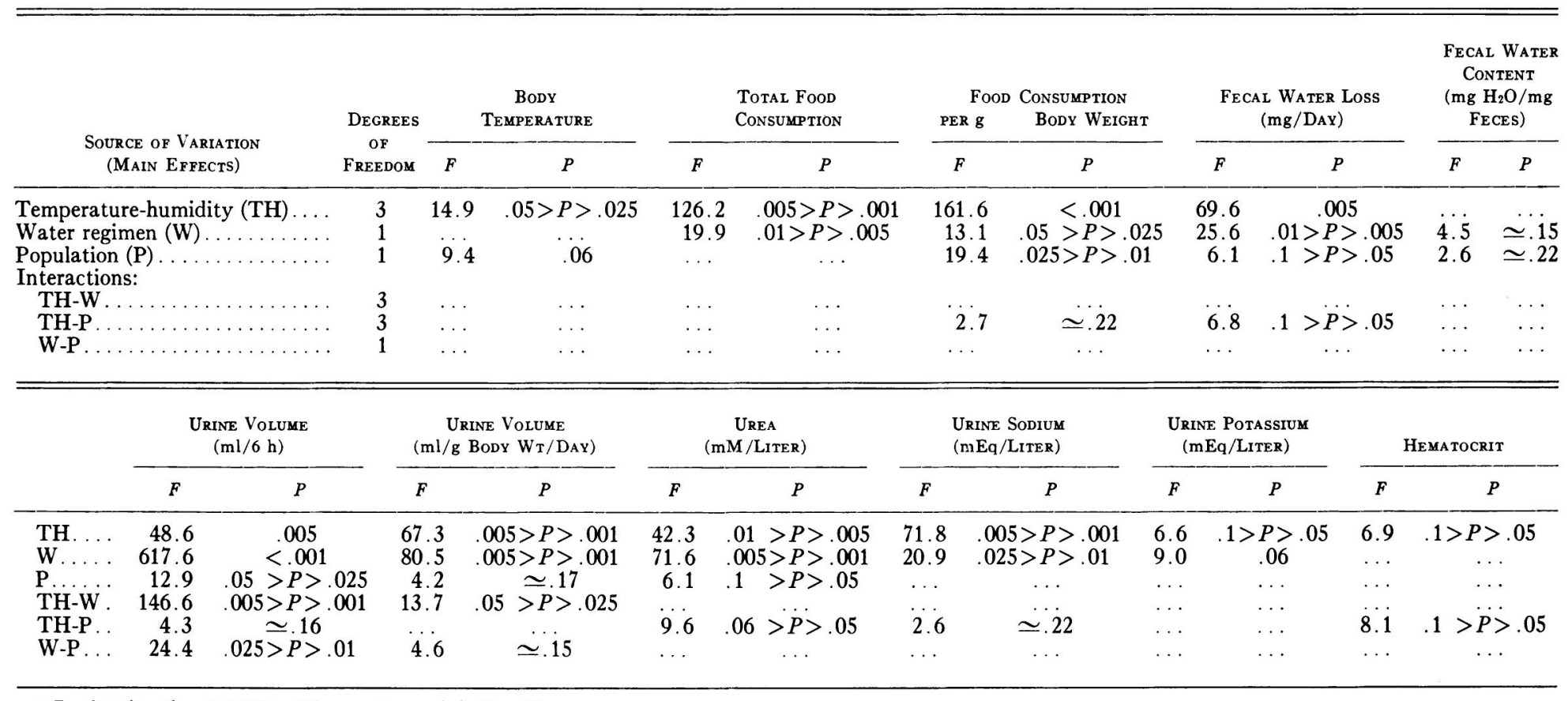

a $F$ values less than $2.5(P>.25)$ are not recorded $N=16$ 

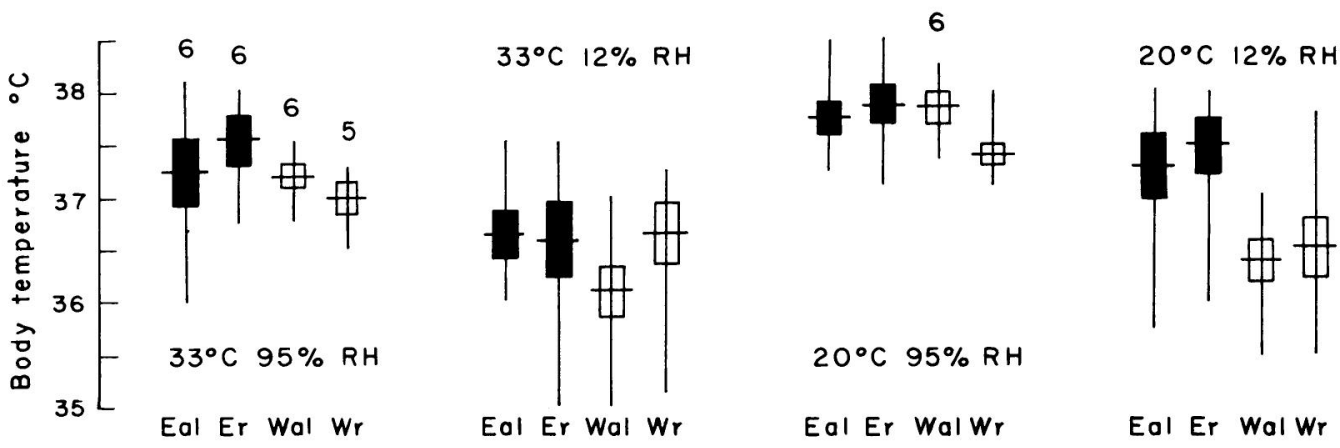

Eal Er Wal Wr

FIG. 3.-Body temperature of eastern (mesic) and western (xeric) populations of harvest mice maintained at four experimental conditions. Vertical line $=$ range of individual means; horizontal line $=$ population mean; vertical bar $=$ standard error of the population mean. Open bars $=$ western (xeric) population; solid bars = eastern (mesic) population. $N=7$; when $<7, N=$ number above vertical line. $E a l=$ eastern ad lib water, $E r=$ eastern restricted water; $W a l=$ western ad lib water, and $W r=$ western restricted water.

TABLE 2

WATER CONSUMPTION, AD LIBITUM ${ }^{\mathbf{2}}$

\begin{tabular}{|c|c|c|c|}
\hline \multirow[b]{2}{*}{$\begin{array}{c}\text { EXPERIMENTAL } \\
\text { GROUP }\end{array}$} & \multicolumn{2}{|c|}{$\begin{array}{l}\mathrm{ml} \mathrm{H}_{2} \mathrm{O} / \mathrm{g} \text { BODY } \\
\text { WEIGHT/DAY }\end{array}$} & \multirow[b]{2}{*}{$\begin{array}{c}\text { VPD } \\
\text { (MILLIBARS }\end{array}$} \\
\hline & Mean & $\begin{array}{l}\text { Standard } \\
\text { Error }\end{array}$ & \\
\hline \multicolumn{4}{|l|}{$33 \mathrm{C}, 95 \% \mathrm{RH}:$} \\
\hline Eastern . . . . . & 0.130 & $0.014\}$ & \multirow{2}{*}{2.5} \\
\hline Western ...... & 0.089 & $0.006\}$ & \\
\hline $\begin{array}{c}33 \mathrm{C}, 12 \% \text { RH: } \\
\text { Eastern. }\end{array}$ & & & \multirow{3}{*}{45.4} \\
\hline $\begin{array}{l}\text { Eastern . . . . . . } \\
\text { Western }\end{array}$ & 0.188 & $0.023\}$ & \\
\hline $\begin{array}{l}\text { Western. } \\
20 \mathrm{C}, 95 \% \text { RH: }\end{array}$ & 0.149 & $0.007\}$ & \\
\hline Eastern ........ & 0.194 & $0.032\}$ & \multirow{2}{*}{1.2} \\
\hline Western $\ldots . .$. & 0.118 & $0.008\}$ & \\
\hline $\begin{array}{c}20 \mathrm{C}, 12 \% \mathrm{RH}: \\
\text { Eastern. . . . . }\end{array}$ & & & \multirow[b]{2}{*}{20.5} \\
\hline Western....... & 0.142 & $0.015\}$ & \\
\hline
\end{tabular}

- VPD = vapor pressure deficit. $N=7$ for each group.

with those of the western population indicate more variability in drinking in the population from the mesic habitat.

Animals of both populations drank most $(P<.005)$ during the second testing week (Reaka 1969). There was no consistent relationship between the drinking patterns and the patterns of weight with time, indicating that harvest mice probably do not undergo voluntary periods of dehydration and hydration.

The distributions of drinking water data were skewed toward the lower drinking range; in all experiments a few consistent "drinkers" extended the drinking range many milliliters per day.

\section{F. FOOD-WATER RELATIONSHIPS}

Both populations ate more food at low temperatures and on ad lib water regimens than at high temperatures and restricted water regimens (tables 1,3 ). The eastern animals ate more food per gram body weight than did the larger western animals (tables 1,3 ).

The percentage of water measured in the food was not significantly different in the two experiments at $95 \% \mathrm{RH}$; the grain averaged $11.3 \%$ water by weight. In the two experiments at $12 \% \mathrm{RH}$, the moisture content of the food did not differ significantly; the food contained $6.4 \%$ water by weight. The water in food at $95 \% \mathrm{RH}$ was significantly greater than the water in food at $12 \% \mathrm{RH}(P<$ $.05)$. Less water was obtained from food at high temperatures, on restricted water regimens, and by the western population (per gram body weight) (table 3 ).

Animals in these experiments could not maintain a positive water balance on the unbound water obtained from the 
TABLE 3

MEAN FOOD CONSUMPTION AND WATER OBTAINED FROM FOOD

\begin{tabular}{|c|c|c|c|c|c|c|}
\hline Experiment & $\begin{array}{c}\text { mg Food/ } \\
\text { Day }\end{array}$ & $\begin{array}{c}\mathrm{mg} \text { Unbound } \\
\mathrm{H}_{2} \mathrm{O} / \text { Day }\end{array}$ & $\begin{array}{c}\text { mg Metabolic } \\
\mathrm{H}_{2} \mathrm{O} / \mathrm{Day}\end{array}$ & $\begin{array}{c}\text { mg Food/ } \\
\text { Day/g } \\
\text { Body Weight }\end{array}$ & $\begin{array}{c}\text { mg Unbound } \\
\mathrm{H}_{2} \mathrm{O} / \text { Day } / \mathrm{g} \\
\text { Body Weight }\end{array}$ & $\begin{array}{c}\mathrm{mg} \mathrm{Metabolic} \\
\mathrm{H}_{2} \mathrm{O} / \text { Day } / \mathrm{g} \\
\text { Body Weight }\end{array}$ \\
\hline 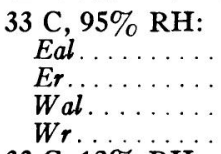 & $\begin{array}{r}1,290 \\
920 \\
990 \\
910\end{array}$ & $\begin{array}{l}145 \\
104 \\
111 \\
103\end{array}$ & $\begin{array}{l}615 \\
439 \\
472 \\
434\end{array}$ & $\begin{array}{r}119 \\
99 \\
98 \\
90\end{array}$ & $\begin{array}{l}13.4 \\
11.2 \\
11.0 \\
10.1\end{array}$ & $\begin{array}{l}56.7 \\
47.2 \\
46.7 \\
42.9\end{array}$ \\
\hline $\begin{array}{c}33 \mathrm{C}, 12 \% \text { RH: } \\
\text { Eal } \ldots \ldots \ldots \ldots \\
\text { Er } \ldots \ldots \ldots \ldots \\
\text { Wal } \ldots \ldots \ldots \ldots \\
\text { Wr } \ldots \ldots \ldots \ldots\end{array}$ & $\begin{array}{r}1,060 \\
800 \\
1,100 \\
940\end{array}$ & $\begin{array}{l}68 \\
51 \\
71 \\
60\end{array}$ & $\begin{array}{l}505 \\
381 \\
524 \\
448\end{array}$ & $\begin{array}{l}88 \\
77 \\
78 \\
78\end{array}$ & $\begin{array}{l}5.7 \\
4.9 \\
5.0 \\
5.0\end{array}$ & $\begin{array}{l}41.9 \\
36.7 \\
37.2 \\
37.2\end{array}$ \\
\hline $\begin{array}{c}20 \mathrm{C}, 95 \% \text { RH: } \\
\text { Eal } \ldots \ldots \ldots \ldots \\
\text { Er. } \ldots \ldots \ldots \\
\text { Wal } \ldots \ldots \ldots \\
W r \ldots \ldots\end{array}$ & $\begin{array}{l}2,420 \\
2,130 \\
2,400 \\
1,840\end{array}$ & $\begin{array}{l}273 \\
243 \\
271 \\
208\end{array}$ & $\begin{array}{r}1,154 \\
1,015 \\
1,144 \\
877\end{array}$ & $\begin{array}{l}221 \\
201 \\
188 \\
152\end{array}$ & $\begin{array}{l}25.0 \\
22.7 \\
21.2 \\
17.2\end{array}$ & $\begin{array}{r}105.4 \\
95.8 \\
89.6 \\
72.5\end{array}$ \\
\hline 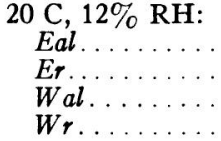 & $\begin{array}{l}2,700 \\
2,150 \\
2,640 \\
2,430\end{array}$ & $\begin{array}{l}174 \\
138 \\
170 \\
157\end{array}$ & $\begin{array}{l}1,287 \\
1,025 \\
1,258 \\
1,158\end{array}$ & $\begin{array}{l}219 \\
185 \\
184 \\
180\end{array}$ & $\begin{array}{l}14.1 \\
11.9 \\
11.8 \\
11.6\end{array}$ & $\begin{array}{r}104.4 \\
88.2 \\
87.2 \\
85.8\end{array}$ \\
\hline
\end{tabular}

food. Scratch grain differs from the natural food of grass seeds, and unbound water from grass seeds may make up a larger proportion of the total water intake than under these laboratory conditions.

Metabolic water supplied a major portion of the daily water intake in our experiments (table 3 ). The western population produced less metabolic water per gram body weight than the eastern population, and all animals produced less metabolic water at high temperatures and on restricted water regimens than in the converse conditions.

\section{G. OXYGEN CONSUMPTION}

Oxygen consumption (table 4) was calculated from the $\mathrm{O}_{2}$ required to metabolize food. The calculation of these data assumes that there is equal efficiency in using $\mathrm{O}_{2}$ for metabolizing food under different temperatures, humidities, and water regimens in two populations. The rate of metabolism of $R$. megalotis not in a nest at $33 \mathrm{C}$ was
TABLE 4

CALCULATED OXYGEN CONSUMPTION $(\mathrm{ml} \mathrm{O} / \mathrm{h} / \mathrm{g})$ OF HARVEST MICE UNDER TWO WATER REGIMENS

\begin{tabular}{cccccc}
\hline \hline & \multicolumn{2}{c}{ EASTERN } & & \multicolumn{2}{c}{ WESTERN } \\
\cline { 2 - 3 } \cline { 5 - 6 } ExPERIMENT & Ad Lib & $\begin{array}{c}\text { Re- } \\
\text { stricted }\end{array}$ & & Ad Lib & $\begin{array}{c}\text { Re- } \\
\text { stricted }\end{array}$ \\
\hline 33 C, 95\% RH & 3.8 & 3.0 & & 2.8 & 2.8 \\
33 C, 12\% RH & 3.0 & 2.3 & & 2.6 & 2.6 \\
20 C, 95\% RH & 7.0 & 6.2 & & 6.0 & 4.7 \\
20 C, $12 \%$ RH & 7.1 & 5.9 & & 5.8 & 5.6
\end{tabular}

2.5-3.0 ml/g per hour and at $20 \mathrm{C}$ was about $6.0 \mathrm{ml} / \mathrm{g}$ per hour (Pearson $1960 b)$. These data are comparable to our calculated results (table 4).

In general, the western population had lower rates of metabolism than the eastern population, and animals on restricted water intake had lower rates of oxygen consumption than animals provided water ad lib.

$$
\text { H. FECAL WATER LOSS }
$$

Daily fecal water loss is a function of the number of feces per day and the 
amount of water per fecal pellet. The rate of defecation was related to food consumption; the variables which significantly affected food consumption (table 1) also significantly affected fecal production (all $P<.005$ ). A temperaturehumidity-water interaction $(P<.005)$ shows that the difference between defecation rates of restricted versus ad lib animals is much greater at low humidities than at high humidities.

The fecal water content was not significantly affected by the temperaturehumidity regimens (tables 1,5 ). However, the fecal water content generally was lower under restricted water regimens than under ad lib regimens. Usually the mean fecal water content was lower in the western population than in the eastern population, but this relationship may not be significant (table 1).

Fecal water loss was affected by the temperature-humidity regimen (table 1). Animals on restricted water lost less fecal water per day than did animals on ad lib water (table 5). Less fecal water loss occurred at higher humidities and at higher temperatures. In general, western animals lost less fecal water than did eastern animals.

\section{EVAPORATIVE WATER LOSS}

Total evaporative water loss was significantly greater at $35 \mathrm{C}$ than at $25 \mathrm{C}(F[1,76]=542.3, P<.001)$. There was also a significant population effect $(F[1,76]=34.9, P<.001)$ and a significant interaction between population and temperature $(F[1,76]=42.5, P<$ $.001)$. The eastern population lost more water at $25 \mathrm{C}$ and the western at $35 \mathrm{C}$.

Weight-specific evaporative water loss was much greater at $35 \mathrm{C}$ than at $25 \mathrm{C}$ (fig. 4). There were no significant population effects, but the interaction between population and temperature was nearly significant. The western animals lost

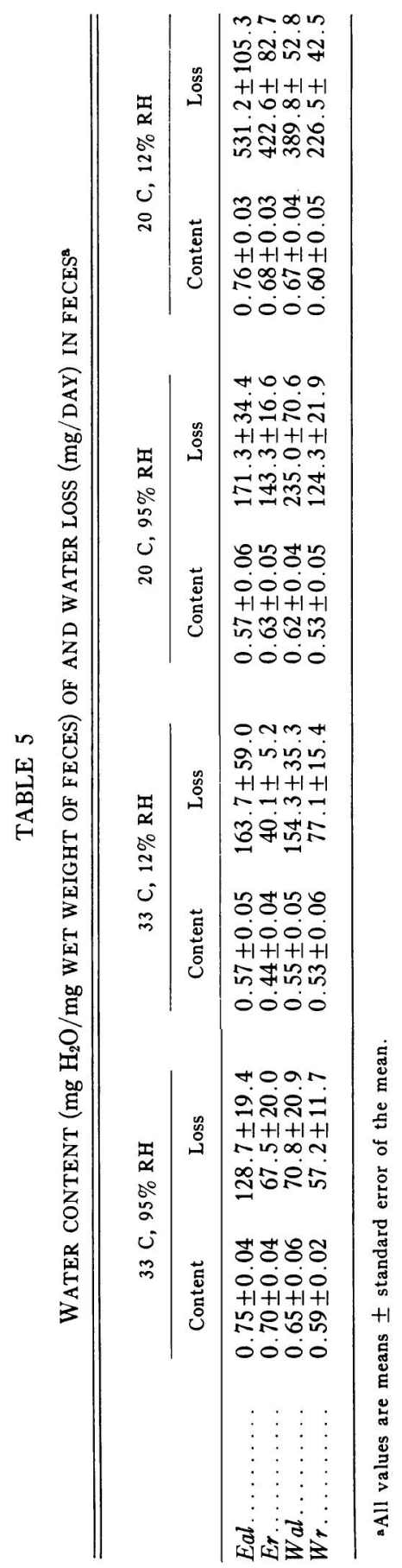


more water per gram body weight than did the eastern mice at $35 \mathrm{C}$; the eastern animals lost more at $25 \mathrm{C}$ (fig. 4).

Calculations of evaporative water loss relative to metabolic rate suggest that the western population lost less evaporative water relative to oxygen consumed at 20-25 $\mathrm{C}$ than did the eastern population (fig. 4). However, at about $26 \mathrm{C}$ the western population began to lose more evaporative water than did the eastern population.

During heat stress the lightly haired feet and the fur of the proximal parts of all the legs of both populations were wet, even when salivation was not observed. Possibly the feet of $R$. megalotis may be sites of cooling through evaporation and conductance to the substratum.
Salivation was a major source of water loss in harvest mice at high temperatures. At $33 \mathrm{C}$ and $95 \% \mathrm{RH}$ the fur of the face, throat, sides, and venter was wet. In completely dried air, salivation occurred only in some animals at $35 \mathrm{C}$.

$$
\text { J. URINE AND BLOOD }
$$

Urine volume $(\mathrm{ml} / 6 \mathrm{~h})$ was significantly affected by the temperaturehumidity regimen, the water regimen, and the population (table 1). There were interactions among all three main effects. Urine volumes were lower under restricted water regimen than under ad lib water (fig. 5). Urine volume was maximal at 20 and $12 \% \mathrm{RH}$, ad lib. Urine production under restricted water regi-

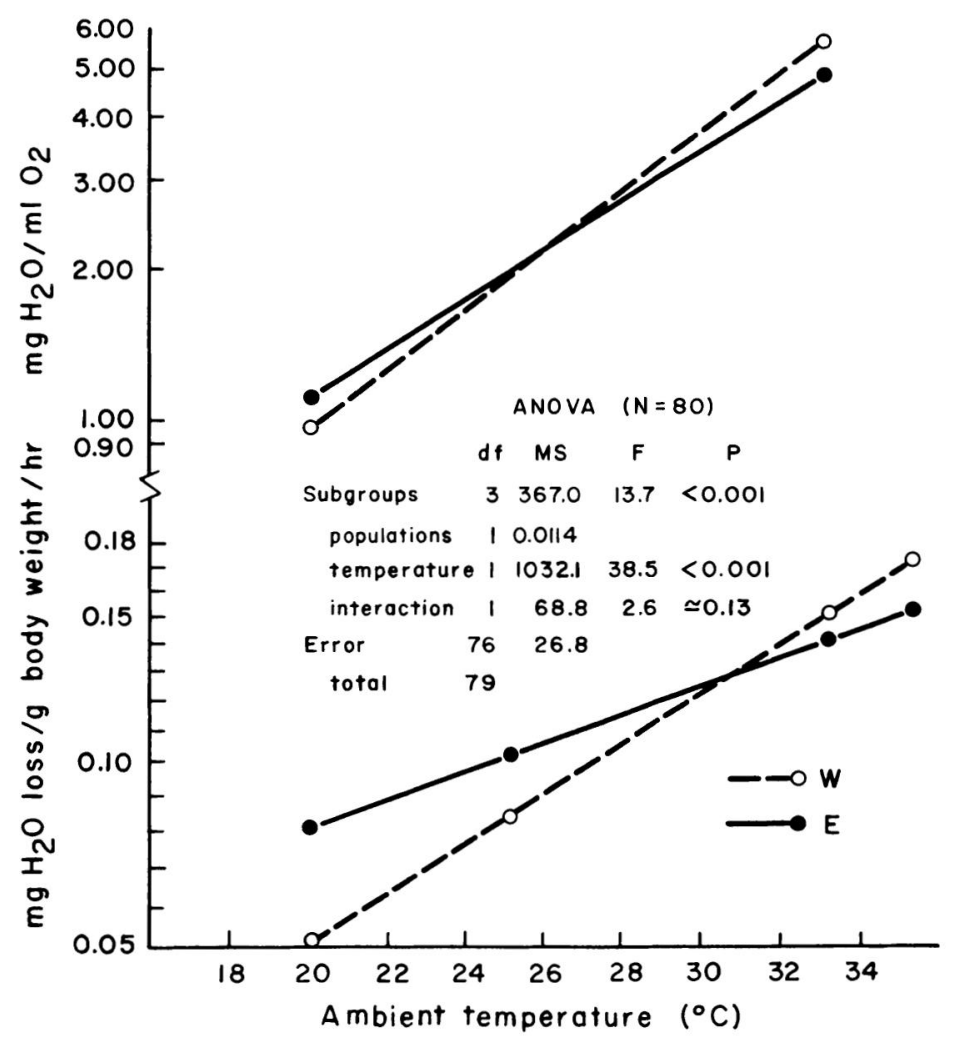

FIg. 4.--Evaporative water loss in dry air. Data at 25 and $35 \mathrm{C}$ were measured; data for 20 and $33 \mathrm{C}$ were calculated for comparison with other experiments, assuming a logarithmic rate of water loss between 20 and 35 C. See table 1 (ANOVA) for measured rates. 
men varied little, except it was maximal at $33 \mathrm{C}$ and $95 \% \mathrm{RH}$.

Urine volume calculated per gram body weight was significantly affected by the temperature-humidity regimen and the water regimen (table 1). There was a smaller population effect, and interactions were less apparent. Overall trends were similar to those described for non-weight-specific urine production (fig. $5)$.

The concentrations of $\mathrm{Na}^{+}, \mathrm{K}^{+}$, and urea were inversely related to urine volume and were affected by the humidity-temperature regimen and the water regimen (table 1). The concentration of urea was affected also by a temperaturehumidity-population interaction. Population effects were apparent only for urea concentration.
The mean urea concentration was greater in the western than in the eastern mice at high temperature and low humidity but was greater in the eastern than in the western mice at all other experimental conditions (fig. 6). Urea concentrations were greater on restricted than on ad lib water regimens (fig. 6).

The general trends of $\mathrm{K}^{+}$and $\mathrm{Na}^{+}$ were similar (figs. 7,8 ), although urine concentrations of $\mathrm{K}^{+}$were less affected by the experimental treatments. Generally, urine $\mathrm{K}^{+}$and $\mathrm{Na}^{+}$concentrations were higher under restricted than under ad lib water regimens. The major temperature-humidity effect was the lower ion concentration in urine from animals maintained at $33 \mathrm{C}$ and $95 \% \mathrm{RH}$.

The mean urine osmolalities estimated by doubling the electrolyte concentra-

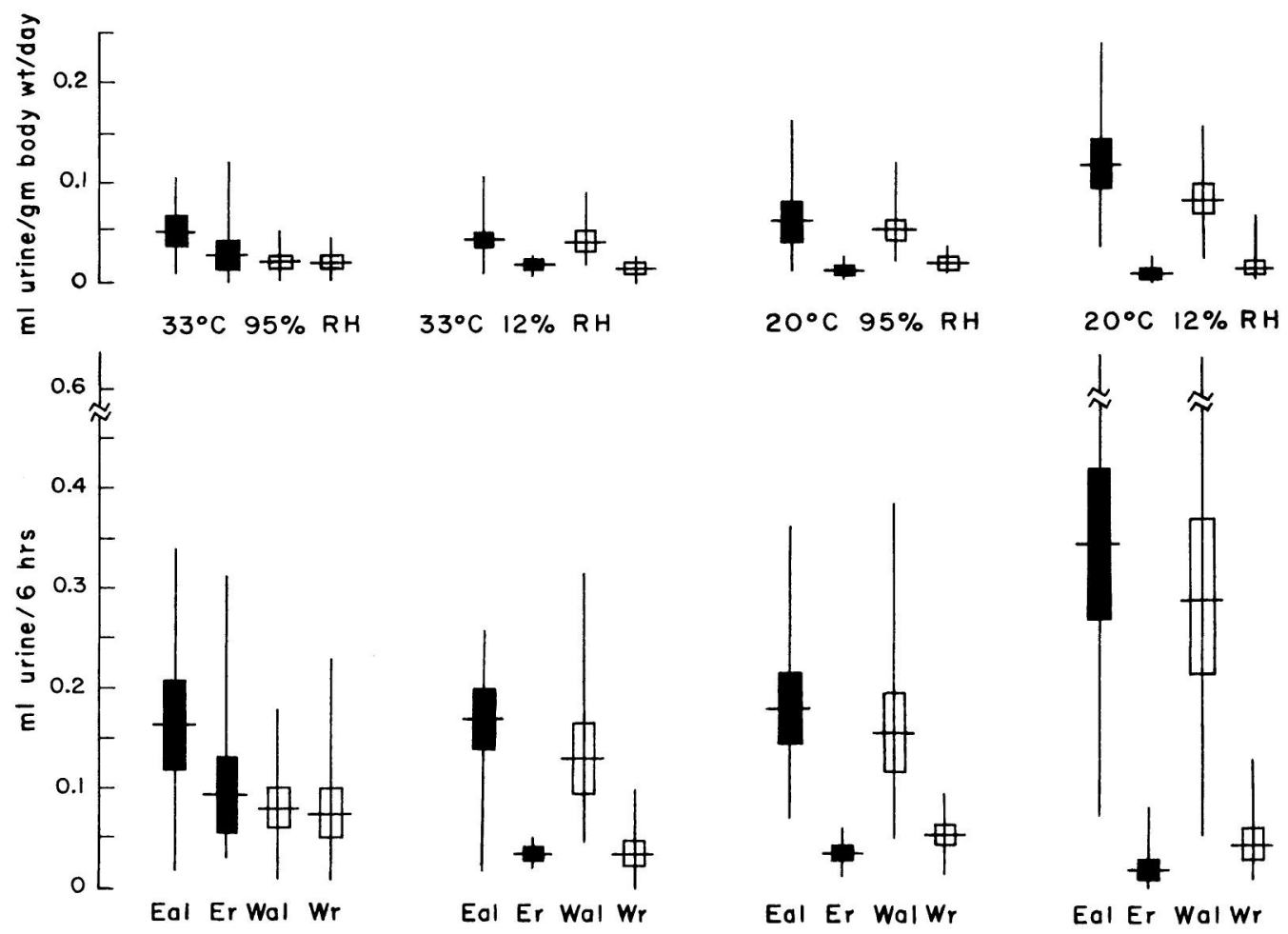

Fig. 5.-Urine production in harvest mice maintained at four experimental conditions. Symbols as in fig. 3. $N=7$ in each population at each condition. 


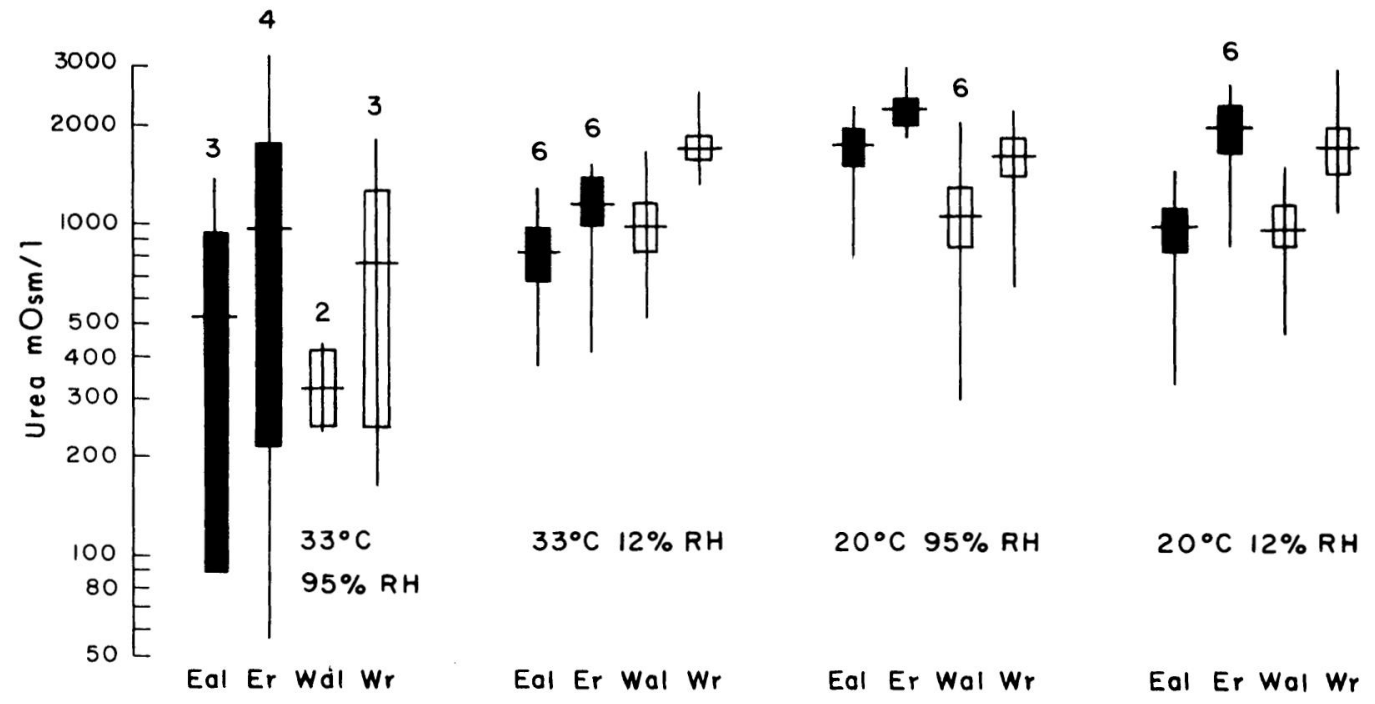

FIG. 6.-The concentration of urea in urine from harvest mice maintained at four experimental conditions. Symbols as in fig. 3 .
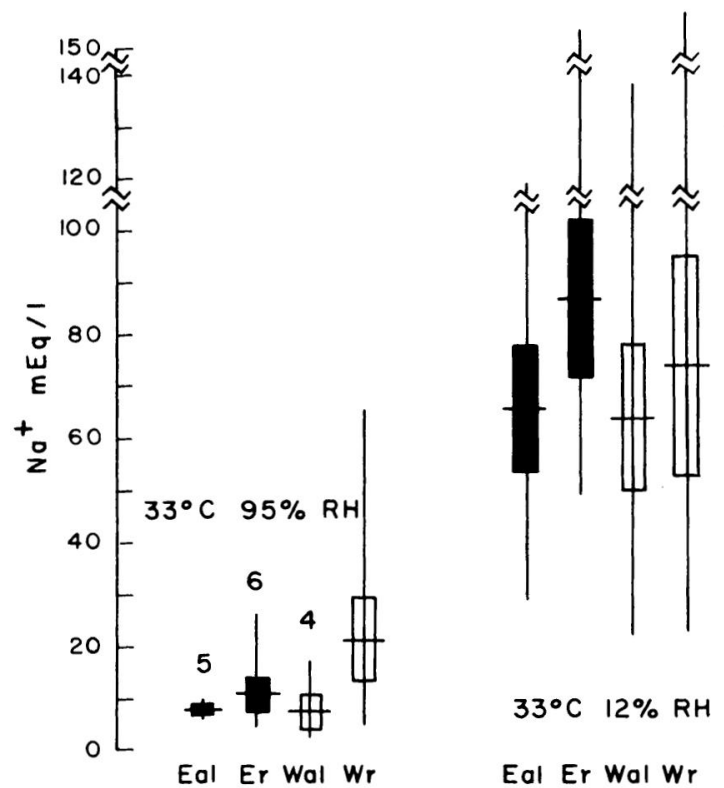

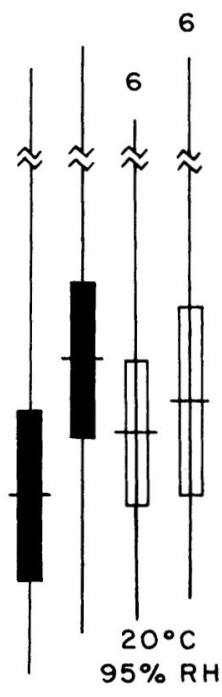

Eal Er Wal Wr

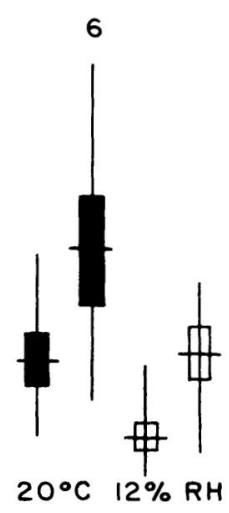

Eal Er Wal Wr

Fig. 7.- The concentration of $\mathrm{Na}^{+}$in urine from harvest mice maintained at four experimental conditions. Symbols as in fig. 3 . 

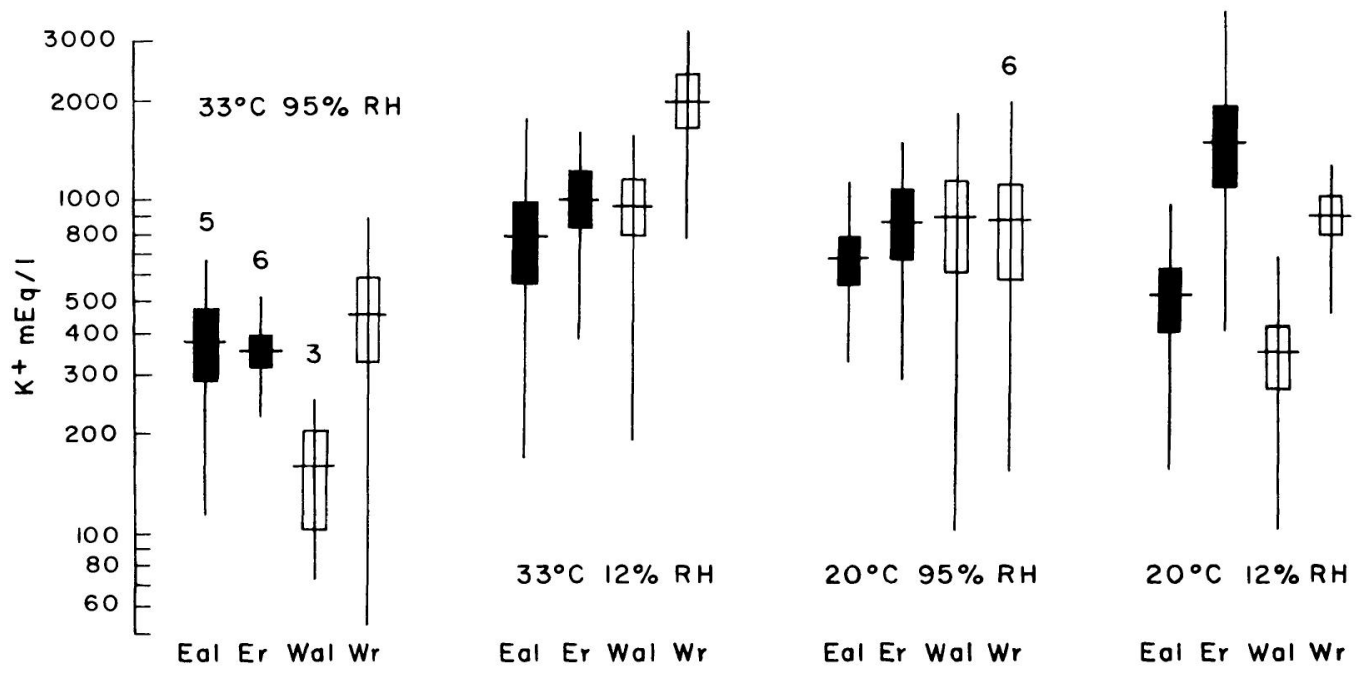

Fig. 8. - The concentration of $\mathrm{K}^{+}$in urine from harvest mice maintained at four experimental conditions. Symbols as in fig. 3.

tions and adding the urea concentration (MacMillen and Lee 1967) ranged from 1,302 to $5,438 \mathrm{mosmol} /$ liter (Reaka 1969). In general, osmolality was higher under restricted water regimens and at lower humidity (higher VPD).

To compare the blood concentration with the urine concentration, plasma ions and hematocrits were measured. Plasma ion $\left(\mathrm{Na}^{+}, \mathrm{K}^{+}\right)$concentrations did not vary consistently with the environmental variables tested or between the populations (Reaka 1969). The overall mean plasma $\mathrm{K}^{+}$was $26 \mathrm{mEq} /$ liter, and plasma $\mathrm{Na}^{+}$was $413 \mathrm{mEq} /$ liter.

Electrolyte urine/plasma $(\mathrm{U} / \mathrm{P})$ ratios were higher in the western population at $33 \mathrm{C}$ but were usually higher in the eastern population at $20 \mathrm{C}$ (Reaka 1969). The highest $U / P$ ratio of 4.3 occurred in the western population at $33 \mathrm{C}$ and $12 \% \mathrm{RH}$.

The hematocrits (fig. 9) were higher at high humidities than at low humidities, which probably accounts for the temperature-humidity effects (table 1). The interaction between population and temperature-humidity effects occurred because the western population had a lower hematocrit than did the eastern population at $20 \mathrm{C}$, especially at $95 \%$ $\mathrm{RH}$. There were greater differences in hematocrits between eastern and western populations than between ad lib and restricted water regimens.

$$
\text { K. TOTAL WATER BALANCE }
$$

The importance of metabolic water relative to the entire water intake was greatest at low temperatures and when animals were on restricted water regimens (fig. 10). Metabolic water was far more important in water balance than unbound water obtained in grain, suggesting that effective water conservation enables these mice to utilize seeds rather than green vegetation or insects as food (Fisler 1965).

Urinary water loss was more significant than fecal water loss, although a notable exception occurred at $20 \mathrm{C}$ and $12 \%$ RH. Evaporation was by far the most important source of water loss (see caption to fig. 10).

At high humidities, the total amount of water consumed and lost by the 

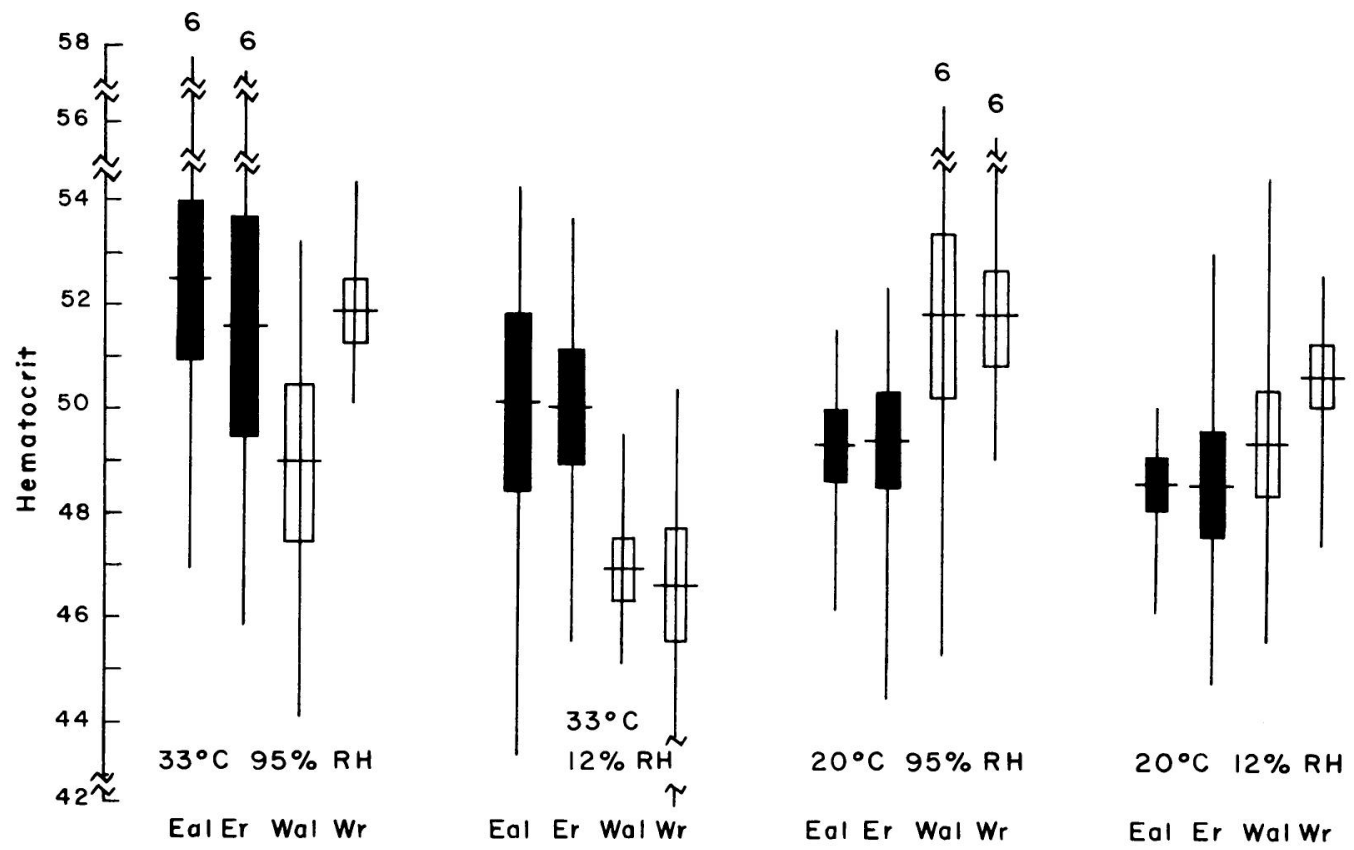

Fig. 9.-Hemotocrit from harvest mice maintained at four experimental conditions. Symbols as in fig. 3.
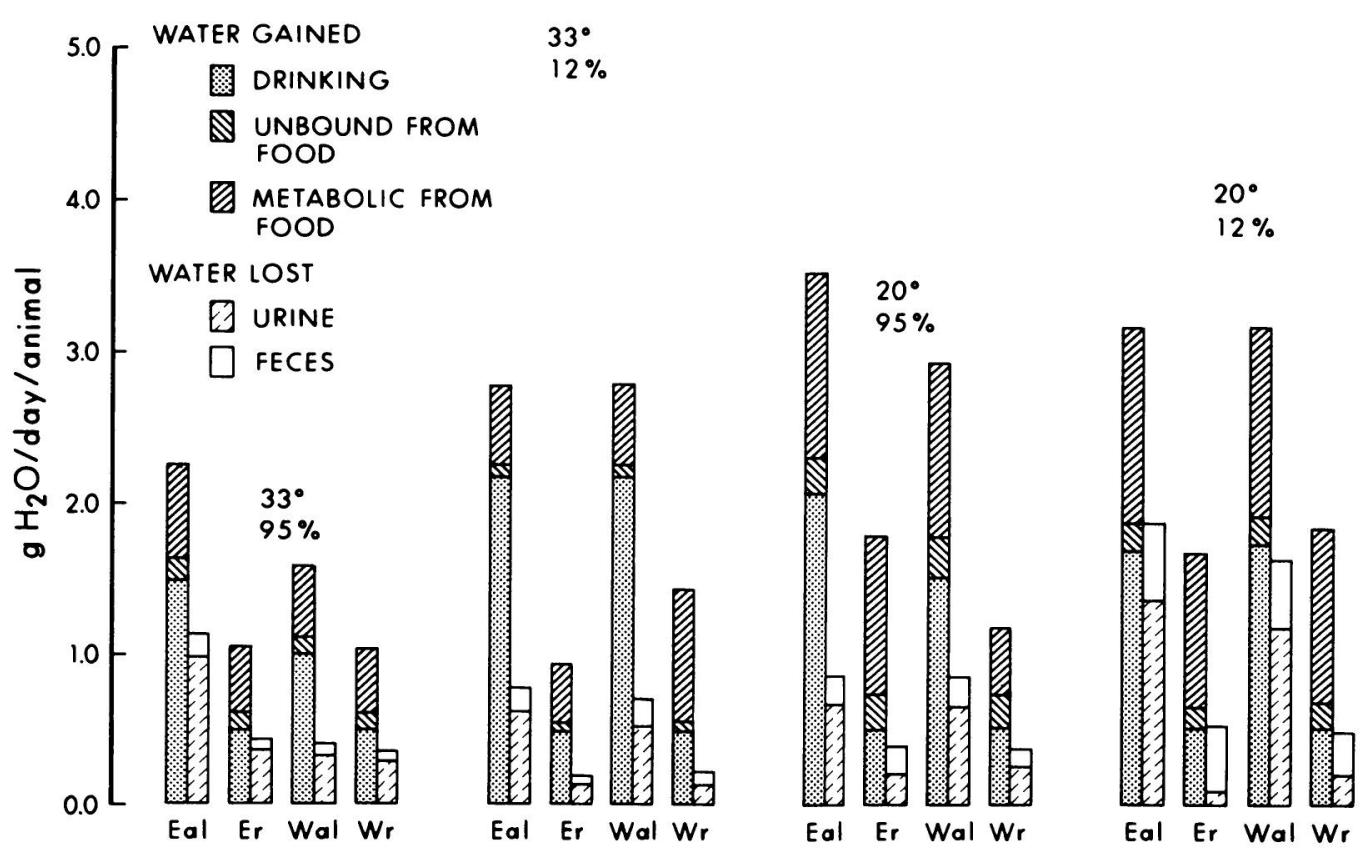

Fig. 10.-Total water balance per animal per day. Because body weight of animals was at equilibrium, the difference between water gained and water lost represents evaporative water loss. 
eastern groups was greater than the water turnover by the western groups. When water obtained and lost is expressed in percentage weight, turnover in the western groups was consistently lower than in the eastern groups (Reaka 1969).

\section{DISCUSSION}

A. TOLERANCE OF XERIC CONDITIONS

Heat tolerated by Kansas harvest mice was greater than that by Reithrodontomys megalotis from California (Pearson $1960 b)$.

While harvest mice from eastern and western Kansas weighed about $73 \%$ and $62 \%$ of original weight before death, $R$. megalotis from near San Francisco Bay weighed about $58 \%$ of original weight at death (our calculation from Fisler [1963]). Inland populations of $R$. megalotis from southern California tolerate loss to $54.8 \%$ (mean) of original weight before death (MacMillen 1964).

The western Kansas population lost an average of $4.8 \%$ and the eastern population an average of $8.9 \%$ of original weight per day during the experiment or until death of the individual. Reithrodontomys megalotis from the San Francisco Bay region lost about $11 \%$ body weight per day (our calculation using $9.8 \mathrm{~g}$ as mean body weight) when deprived of water under normal laboratory conditions (Fisler 1963). However, MacMillen (1964) reports a loss of $2.2 \%$ weight per day in inland and $1.9 \%$ weight per day in salt marsh $R$. megalotis from southern California (calculated from half the number of days to death) under moderate laboratory conditions and water deprivation. Thus, $R$. megalotis from southern California survive longer and lose weight at slower rates than do groups from Kansas and central California. However, populations from xeric Kansas environments, the San
Francisco Bay region, and inland southern California tolerate loss of $35 \%-50 \%$ of body weight before death; in contrast, the mesic Kansas population and the southern California salt marsh population tolerate loss of only about $27 \%$ body weight before death.

\section{B. WEIGHT RESPONSES IN SEQUEN-} TIAL EXPERIMENTS

Weight stabilization following an initial weight loss is a characteristic response to tolerable osmotic stress in small mammals. This pattern occurred in $R$. megalotis (MacMillen 1964), in $R$. raviventris (Haines 1964), and in many other rodents (Chew 1965; Haines and Schmidt-Nielsen 1967; MacMillen and Lee 1967, 1969).

The eastern and western Kansas harvest mice evidenced contrasting weight responses. The western population lost weight under both high-humidity conditions, even with ad lib water. When the water supply was restricted, however, the eastern population could not tolerate high temperatures with low humidity as well as the western population. These data suggest that the western population requires low humidity because it cannot tolerate even a $20 \mathrm{C}$ heat load, the eastern population cannot tolerate desiccation, and the western population is more effective at evaporative cooling at high ambient temperature and low humidity.

\section{BEHAVIOR}

The difference in behavior between lowland and mountain forms of Peromyscus maniculatus in laboratory tests accounted for the measured difference in "basal metabolic rate" (Murie 1961). The difference in behavior of our populations of harvest mice likewise may have biased certain laboratory results, but these same behavioral traits would 
affect physiological responses under natural conditions. The more docile western mice consumed less oxygen. Reduced metabolism is associated with xeric existence in rodents (Hart 1971) and probably is a mechanism for conserving water (Willems and Armitage 1975b). The phlegmatic behavior of the western, xeric population of mice may reduce heat production and conserve water.

\section{BODY TEMPERATURE}

A lowered body temperature, lability of body temperature, and tolerance of an elevated body temperature are often considered adaptations to a desert environment (e.g., Dawson 1955; McNab and Morrison 1963). However, Murie (1961) described behavioral causes for a difference in body temperatures in different environments, and Lee (1963) and Hayward (1965) did not find such a correlation between body temperature and xeric environment. Our study showed a depression of body temperature in the xeric population but not more lability or variation in the body temperature of the western population than in the eastern. Differences between the two populations were less than the variation in body temperatures with environmental variables. The western population generally maintained a lower body temperature than did the eastern population either on a restricted water regimen or when VPD was high, or both. Body temperatures of chipmunks show a similar pattern: those from a xeric habitat had lower temperatures than did those from a mesic habitat when they were kept in dry air at a high temperature (Willems and Armitage 1975a).

$$
\text { E. WATER CONSUMPTION }
$$

Humidity affects water consumption of some species (e.g., Getz 1963; Carpen- ter 1966) but not others (Getz 1962, 1963). When on an ad lib regimen at high humidities, eastern harvest mice drank more variably than did the western group. The increased variability of drinking at high humidities in the eastern population may be related to drooling in this group. Carpenter (1966) found that ad lib drinking of Dipodomys agilis from a mesic habitat was much more variable than drinking of $D$. merriami from a xeric habitat.

In many species the amount of water voluntarily obtained corresponds roughly to the amount of water in the habitat (see Chew [1965] for a summary). Reithrodontomys megalotis from the mesic environment consumed more water than did the western population from the xeric environment (table 2). Reithrodontomys montanus (our observations) from drier uplands in the short-grass prairie drank less $(7.1 \%$ of body weight per day) than did $R$. megalotis (range $8.9 \%-19.4 \%$ of body weight per day).

\section{F. FOOD-WATER RELATIONSHIPS}

Harvest mice could not maintain water balance on the metabolic water produced under the conditions of these experiments. MacMillen (1964) found that at least some individuals of $R$. megalotis and of $R$. fulvescens survived on metabolic water alone. High humidity enables some rodents to maintain a positive water balance on metabolic water (Schmidt-Nielsen and SchmidtNielsen 1951; Haines and SchmidtNielsen 1967). High humidity did not enable $R$. megalotis in this study to maintain water balance on metabolic water. On restricted water regimens, which may be closer to natural conditions, metabolic water in this study became more significant relative to the total water intake. Chew (1951) found the same trend in Peromyscus. 
G. FECAL WATER LOSS

The percentages $(44 \%-55 \%)$ of water in the feces in $R$. megalotis are similar to those of desert rodents (e.g., SchmidtNielsen and Schmidt-Nielsen 1951; MacMillen and Lee 1967). The significant point of this study is that fecal water loss varied between populations from different environments and with water regimens. Although the amount of fecal water is small, even a very small advantage in efficiency of water conservation could enable an animal to exist in a marginal environment.

\section{H. EVAPORATIVE WATER LOSS}

If our method of calculating the amount of $\mathrm{H}_{2} \mathrm{O}$ evaporated compared with the amount of $\mathrm{O}_{2}$ consumed is comparable to the methods used in other studies, Reithrodontomys at comparable temperatures evaporated more water per unit oxygen consumed than did the cricetids, Peromyscus eremicus (MacMillen 1965), P. crinitus, Cricetus aureus (Schmidt-Nielsen and Schmidt-Nielsen 1950), and Neotoma lepida (Lee 1963); the murids (Schmidt-Nielsen and Schmidt-Nielsen 1950; MacMillen and Lee 1967); the heteromyids (SchmidtNielsen and Schmidt-Nielsen 1950; Carpenter 1966); and the sciurid Ammospermophilus leucurus (Hudson 1962). Water evaporated compared with $\mathrm{O}_{2}$ consumed by harvest mice was comparable to that of Spermophilus tereticaudus at $20 \mathrm{C}$ but was considerably higher than the latter at $33 \mathrm{C}$ (Hudson 1964).

The flow rates used in this experiment were higher than in many other experiments. High flow rates promote minimal humidities; therefore, high evaporative water loss (EWL) would be expected. Even allowing for the effects of the higher flow rates, harvest mice apparently are ill-adapted to conserving evapora- tive water compared with desert species. Reithrodontomys megalotis from California are active in the cooler and more humid conditions of the available environment and are less active in the field during the summer (Pearson 1960a), perhaps because of their high evaporative water loss.

\section{URINE AND BLOOD}

The minor variation in urine volumes in animals on a restricted water regimen (fig. 7) suggests that the minimal volume necessary to excrete nitrogenous wastes was reached.

The mean values of urea in the urine of Reithrodontomys were not extremely high compared with other cricetids, for example, $R$. raviventris (Haines 1964), Onychomys torridus (Schmidt-Nielsen and Haines 1964), and Neotoma albigula (Schmidt-Nielsen et al. 1948). The maximal value obtained in this study $(3,441$ mosmol/liter) exceeded the highest value of $2,590 \mathrm{mosmol} /$ liter found in R. raviventris on restricted water (Haines 1964). The present study provides the highest concentration known to us of urea found in the urine of any cricetid. Individual measurements of urea concentrations from several harvest mice from eastern Kansas exceeded 3,000 mosmol/liter, which is associated in other rodents with independence from drinking water.

The mean electrolyte concentrations (estimated from $\mathrm{Na}^{+}+\mathrm{K}^{+}$concentrations) of urine from Kansas harvest mice are similar to those (estimated from literature values for $\mathrm{Cl}^{-}$concentrations) of salt marsh $R$. megalotis (MacMillen 1964 ) and $R$. raviventris (Haines 1964).

Reithrodontomys megalotis concentrated urine more than the salt marsh harvest mouse, $R$. raviventris (Haines 1964). The highest mean $(5,438 \mathrm{mosmol} /$ liter in $\mathrm{Wr}$ at $33 \mathrm{C}$ and $12 \% \mathrm{RH})$ is 
higher than the mean values reported for many desert rodents (MacMillen 1972).

Although hematocrits were not consistently affected by experimental conditions, the response of the western population at the highest VPD suggests that plasma volume is maintained for temperature regulation, as suggested by Adolph (1947).

\section{J. COMPARISON OF POPULATIONS AND GENERAL CONCLUSIONS}

The western harvest mouse is a grassland species with a distribution throughout most of central and western North America (Hall and Kelson 1959). Several major changes in the environment probably affected the distribution and the physiological phenotype of the species since the last glacial advance. During the xerothermic period $(2,500-4,000$ yr before the present), grassland extended far east of the present limits of the prairies (Kendeigh 1974, p. 311); the distribution of harvest mice was probably far more widespread than today. Recently (since 2,500 yr before present) the deciduous forest and mesic environment, which now edges near Douglas County, Kansas, has spread westward. Reithrodontomys megalotis have become isolated in pockets of grassland and have either adjusted to the more mesic environment or have not survived. Harvest mice are markedly less abundant in northeastern than in southwestern Kansas.

One would expect to find physiological adaptations among eastern populations for higher temperature-humidity combinations and greater water regimens. Because of lack of active selection for the ancestral (western) adaptations to low humidities and low water fluxes, these adaptations may already have been de- leted from eastern populations or still be present but in the process of elimination from the gene pool. Because of the backlog of ancestral phenotypes and the hypothesized selection for new adaptations, one might expect greater variation in physiological and behavioral response to environmental variables in the eastern mesic than in the western xeric population. In the laboratory many of these expectations were demonstrated.

Neither population of harvest mice would encounter ambient temperatures much in excess of $20 \mathrm{C}$ during their nocturnal activity. At this temperature harvest mice from western Kansas function most efficiently at low humidities (high VPD), as indicated by the tolerance to xeric-conditions test, weight loss data from the four sequential experiments, and fecal water loss. Adaptations of the western population include tolerance of a small water flux, low metabolic rate and body temperature, tolerance of desiccation, low evaporative cooling per gram body weight, and "passive" behavior. Adaptations of the eastern population include tolerance of a heat load when water is abundant, a high water flux, a high metabolic rate and body temperature, and high evaporative cooling per gram body weight. The intraspecific variation between metabolism and water flux in harvest mice parallels the interspecific variations reported for desert rodents (Macfarlane et al. 1971).

The kidney of the western animals seemed to operate more efficiently when environmental temperatures were at 33 $\mathrm{C}$ rather than at $20 \mathrm{C}$, whereas the kidney of the eastern animals operated more efficiently when environmental temperatures were at $20 \mathrm{C}$. The western population has possibly evolved a more favorable relationship between metabolic water production and evaporative water 
loss than the eastern population such that an "effective" kidney is less critical at the lower temperature (MacMillen 1972).

The distribution of $R$. megalotis shows that the success of harvest mice may be related to the factors analyzed in this study. For example, $R$. megalotis does not occur in south central Kansas or in most of Oklahoma and Texas. Temperature tolerance alone is not limiting, because this species occurs in Arizona, New Mexico, and Baja California. The high humidity combined with high temperatures around the Gulf of Mexico may limit the species from the grasslands mentioned above. Although the eastern population in the present study shows some facility for coping with high temperatures coupled with high humidity, increased tolerance to temperature loads occurred only when ample water was avaliable. The mice may not be able to evaporate enough water to maintain body temperature at the high temperature-humidity combination of the Gulf of Mexico region.

However, to say that the species is limited by physiological responses to the environment is an oversimplification; the distribution of this harvest mouse is undoubtedly controlled by intra- and interspecific biological factors as well as by behavioral and physiological adjustments to the environment.

The main result of this study has been to show differences in physiological adaptations to the environment within populations of the same species, even though the populations are separated by small distances. Thus, this study indicates that at least two physiologically different types of harvest mice have emerged within Kansas presumably since the Pleistocene; one of these populations is adapting to a more humid environment than the arid grasslands in which the "ancestral" group is found.

\section{LITERATURE CITED}

Adolph, E. F. 1947. Tolerance to heat and dehydration in several species of mammals. Amer. J. Physiol. 151:564-575.

Carpenter, R. E. 1966. A comparison of thermoregulation and water metabolism in the kangaroo rats, Dipodomys agilis and $D$. merriami. Univ. California Pub. Zool. 78:1-36.

CHEw, R. M. 1951. The water exchanges of some small mammals. Ecol. Monogr. 21 :215-225.

_- 1965. Water metabolism of mammals. Pages 43-178 in W. MAYER and R. VAN GeLDER, eds. Physiological mammalogy. Vol, 2. Academic Press, New York.

Dawson, W. R. 1955. The relation of oxygen consumption to temperature in desert rodents. J. Mammal. 36:543-553.

Fisler, G. F. 1963. Effects of salt water on food and water consumption and weight of harvest mice. Ecology 44 : 604-608.

- 1965 . Adaptations and speciation in harvest mice of the marshes of San Francisco Bay. Univ. California Pub. Zool. 77:1-108.

GeTz, L. L. 1962. Notes on the water balance of the red-backed vole. Ecology 43:565-567.

$\rightarrow$ - 1963. A comparison of the water balance of the prairie and meadow voles. Ecology $44: 202-$ 207.
HaINes, H. 1964. Salt tolerance and water requirements in the salt-marsh harvest mouse. Physiol. Zool. $37: 266-272$.

Haines, H., and K. Schmidt-Nielsen. 1967. Water deprivation in wild house mice. Physiol. Zool. 40:424-431.

Hall, E. R. 1955. Handbook of mammals of Kansas. Univ. Kansas Mus. Natur. Hist. Misc. Pub. 7. $303 \mathrm{pp}$.

Hall, E. R., and K. R. Kelson. 1959. The mammals of North America. Vol. 2. Ronald, New York.

Hart, J. S. 1971. Rodents. Pages 1-149 in G. C. Whitrow, ed. Comparative physiology of thermoregulation. Vol. 2. Academic Press, New York.

Hayward, J. S. 1965. Metabolic rate and its temperature-adaptive significance in six geographic races of Peromyscus. Can. J. Zool. 43:309-323.

Hudson, J. W. 1962. The role of water in the biology of the antelope ground squirrel, Citellus leucurus. Univ. California Pub. Zool. 64:1-56.

. 1964. Water metabolism in desert mammals. Pages 211-235 in Thirst-Proceedings of the First International Symposium on Thirst in the Regulation of Body Water. Pergamon, New York. 